\title{
Understanding Offending Across the Life-Course: Current Theories and Conceptions
}

\author{
Paul Mazerolle ${ }^{1} \cdot$ Tara Renae McGee $^{1}$
}

Published online: 1 September 2020

(C) Springer Nature Switzerland AG 2020

We are delighted to present the latest special issue for the Journal of Developmental and Life-Course Criminology (JDLCC). Our early planning for the JDLCC included a commitment to explore opportunities for showcasing current research on developmental and lifecourse criminology across various thematic areas. We have produced several special issues over recent years and it is timely to illuminate some of the current theories and theoretical debates available for informing understanding of criminal offending across the life-course.

Theories provide the foundation, indeed the lifeblood for advancing knowledge and understanding about crime across the life-course. Over the past 30years, we have observed considerable growth in the range of theoretical contributions examining crime across the lifecourse. Indeed, the depth and breadth of theories that have emerged over this time are impressive. As research findings about criminal offending have accumulated, so too has the range of significant questions and queries about dynamic offending sequences and stages of offending behavior across the life-course. The expanded collection of research findings has magnified the need and importance of furthering the theoretical foundations for explaining and understanding criminal behavior across the life-course. What has emerged is a range of approaches, from general theories to typological theories, from static to dynamic approaches, as well as various combinations (Paternoster et al. 1997).

The advance of developmental and life-course criminology over time stems from the convergence of a range of related activities. For example, while the relationship between age and crime is often viewed as one of the "brute facts" of criminology, it has only been over the past 30 years that major debates and disagreements have emerged over the nature and interpretation of this important relationship (Blumstein et al. 1988; Hirschi and Gottfredson 1995; Gottfredson and Hirschi 1990; Sampson and Laub 1995). Vigorous debates over the age-crime relationship and its interpretation were occurring at a time when the criminal career paradigm for partitioning and predicting correlates of dimensions of offending behavior (onset, persistence, escalation, desistance, etc.) were highly prevalent. Moreover, at this time, researchers were increasingly able to access longitudinal data sets and were

Paul Mazerolle

pjm2@unb.ca

1 Griffith, Griffith University, Brisbane, Australia 
examining processes of offending continuity and change over time. The expansion of research opportunities assessing dynamic offending processes, the accumulation of research findings, and the contrasting interpretations of the relationships between age, development, and crime fueled important advancements in theoretical development and debate (Moffitt 1993; Sampson and Laub 1993; Thornberry 1989).

The rise of and framing toward a distinctive developmental and life-course criminology have, in effect, been shaped by the aforementioned developments and convergences. Emerging through this period has been an expanded vocabulary and recognition of the various concepts and dimensions of offending that require specific attention. This includes considerations of concepts such as offending onset, escalation, and persistence, the importance of pathways, trajectories, and turning points, the role of time stable individual differences, and dynamic, state-dependent processes shaped by local life circumstances (Nagin and Paternoster 1991; Nagin and Paternoster 2000). At the same time, theoretical developments in advancing understanding of crime across the life-course have considered early and later stages of the life-course as well as processes that have general application to explaining most offending behavior (Cullen 1994) as opposed to distinctive or more specific explanations that account for distinctive offending typologies (Moffitt 1993; Patterson et al. 1989; Patterson and Yoerger 1993) or paths to criminal behavior, with unique precursors and risks for offending persistence. Such diversity of thought illustrates the richness of the theoretical landscape of developmental and life-course criminology (McGee and Farrington 2019).

What does the future hold for the theoretical foundations of developmental and life-course criminology? Over time, we can expect that the accumulation of research findings, improvements in measurement, access to data, and sophisticated analytical procedures will challenge some theoretical positions. This kind of theoretical competition is healthy and could foster greater integration of thought as well as an expansion of inter-disciplinary theories of criminal offending across the life-course (Wellford 1989). At the same time, the accumulation of research findings and convergence of theoretical approaches can be further spurned by a rise of new ideas, indeed paradigms, for conceptualizing and understanding of crime over the life-course.

It is without a doubt that numerous opportunities for advancing theoretical and empirical understanding of crime over the life-course are available. As research findings are re-evaluated, research questions are refined, data collection and measurement are improved, and theoretical reflections and conceptions are advanced, new theoretical approaches will emerge that continue to challenge, advance, and improve upon the theoretical status quo. It is our view that the papers included in this thematic issue will materially contribute to these transitions toward a future state with a more refined theoretical understanding of criminal offending across the life-course.

In this special issue, we bring together a series of papers that provide updates of prior developmental and life-course theories as well as papers that examine important dimensions of offending behavior while addressing differing theoretical perspectives or interpretations. In the lead paper, we are pleased to present the Inaugural David P. Farrington Lecture paper. This lecture is delivered by scholars receiving the Life-Time Achievement Award from the American Society of Criminology's Division of Developmental and Life-Course Criminology. In 2017, the dual recipients of this award were 
John Laub and Robert Sampson. In their paper Life-Course and Developmental Criminology: Looking Back, Moving Forward, they first consider the foundations of the discipline both in terms of the data that have been collected and the techniques developed for analyses. Laub and Sampson also consider the theoretical heritage and development of the discipline. Using the same framing of ideas, they consider the many challenges for the discipline in moving forward before providing a more detailed consideration of elements important to their age-graded theory of informal social control with a particular focus on turning points.

David Farrington presents The Integrated Cognitive Antisocial Potential (ICAP) Theory: Past, Present, and Future in the second paper of this special issue. As the title suggests, the development and different iterations of the ICAP theory which provides a focus on the construct of antisocial potential are presented. The theory provides an explanation for the way in which long-term and short-term antisocial potential converge to lead to the commission of criminal acts or antisocial behavior. Farrington summarizes a range of empirical tests of the theory before outlining areas where the theory could be refined and improved in the future. He provides suggestions for ways to test ICAP theory as well as developmental and life-course criminology theories more generally.

In the third paper, P-O Wikström explains the Developmental Ecological Action (DEA) Model, which is a key component of his Situational Action Theory. A central argument of Wikstöm's work, in Explaining Crime and Criminal Careers: the DEA Model of Situational Action Theory, is the need to understand the causes of crime in order to explain criminal careers and pathways to crime. He outlines some of the limitations of developmental and life-course criminology, in particular the focus on risk factors rather than causal factors. Wikstöm then provides a summary of the most up-todate empirical testing of Situational Action Theory before providing a detailed description of the DEA model and the drivers of stability and change within this model. Against this backdrop, he provides suggestions for the prevention of crime.

In contrast to antisocial potential and situational action, Cecilia Chouhy, Francis T. Cullen, and Heejin Lee consider the utility of social support as an organizing concept for developmental and life-course criminology. In their paper A Social Support Theory of Desistance, Chouhy, Cullen, and Heejin consider the role of social support in four ways. Firstly, they consider the components of social support embedded in Sampson and Laub's (1993) age-graded theory of informal social control. This is followed by an examination of the desistance literature and the idea of redemption scripts, arguing that the origin of these is through social support. Third, they consider the role of the correctional system in providing social support. They note that harsher penalties do not deter future criminal involvement but that when social support mechanisms are embedded in correctional institutions, programs are more effective at reducing recidivism. Finally, the importance of social support in coping with negative life events and affect is considered. They provide readers with a detailed pathway forward for a research agenda examining the role of social support in desistance.

The final two papers in this special issue build on an earlier theoretical paper published by Paternoster (2017) in this journal and Cullen's (2017) response to that paper. In the first of the two papers in this issue, Timothy Brezina argues that the points of contention raised by Cullen can be addressed by incorporating Bandura's sociocognitive approach to agency. In doing so, Brezina argues that this leads to asking when and under what conditions is the meaningful exercise of agency likely to occur? 
In a response to this ongoing conversation in the journal, Alex Piquero provides a commentary paper titled A Place for Agency, a Place for Positivism, a Place for Both over the Life Course. In this final paper of the special issue, Piquero traces the debate through the papers by Paternoster (2017), Cullen (2017), and Brezina (this issue). After providing his commentary, Piquero provides a very useful set of questions for researchers interested in progressing this concept both theoretically and empirically.

The collection of these papers illustrates the importance of theories for advancing understanding of crime across the life-course. Of course, the included papers provide only a snapshot of the theoretical diversity and richness of existing theoretical approaches. However, as a collection, they illustrate intellectual depth and sophistication, and reinforce the importance of the role of theories for framing conceptions of criminal offending across the life-course. Clearly, the building blocks are available for advancing improvements in theoretical understanding of criminal offending processes of continuity and change across the life-course.

\section{References}

Blumstein, A., Cohen, J., \& Farrington, D. P. (1988). Criminal career research: it's value for criminology. Criminology, 26, 1-35.

Cullen, F. T. (1994). Social support as an organizing concept for criminology: presidential address to the academic of criminal justice sciences. Justice Quarterly, 11, 527-559.

Cullen, F. T. (2017). Choosing our criminological future: reservations about human agency as an organizing concept. Journal of Developmental and Life-Course Criminology, 3, 373-379.

Gottfredson, M., \& Hirschi, T. (1990). A general theory of crime. Palo Alto, CA: Stanford University Press.

Hirschi, T., \& Gottfredson, M. (1983). Age and the explanation of crime. American Journal of Sociology, 89, $552-584$.

Hirschi, T., \& Gottfredson, M. (1995). Control theory and the life-course perspective. Studies on Crime \& Crime Prevention, 4, 131-142.

McGee, T. R., \& Farrington, D. P. (2019). Developmental and life-course explanations of offending. Psychology, Crime \& Law, 25(6), 609-625.

Moffitt, T. E. (1993). Life-course-persistent and adolescent-limited anti-social behavior. A developmental taxonomy. Psychological Review, 100, 674-701.

Nagin, D., \& Paternoster, R. (1991). On the relationship of past and future participation in delinquency. Criminology, 29, 163-189.

Nagin, D., \& Paternoster, R. (2000). Population heterogeneity and state dependence: state of the evidence and directions for future research. Journal of Quantitative Criminology, 16, 117-144.

Paternoster, R. (2017). Happenings, acts, and actions: articulating the meaning and implications of human agency for criminology. Journal of Developmental and Life-Course Criminology, 3, 350-372.

Paternoster, R., Dean, C. W., Piquero, A., Mazerolle, P., \& Brame, R. (1997). Generality, continuity and change in offending. Journal of Quantitative Criminology, 13, 231-266.

Patterson, G. R., \& Yoerger, K. (1993). A model for early onset of delinquent behavior. In S. Hodgins (Ed.), Mental disorder and crime. Newbury Park: Sage.

Patterson, G. R., DeBaryshe, B. D., \& Ramsey, E. (1989). A developmental perspective on antisocial behavior. American Psychologist, 44, 329-355.

Sampson, R., \& Laub, J. H. (1993). Crime in the Making. In Crime in the making: pathways and turning points through life. Cambridge, MA: Harvard University Press.

Sampson, R., \& Laub, J. (1995). Understanding variability in lives through time: contributions of life-course criminology. Studies on Crime \& Crime Prevention, 4, 14-158.

Thornberry, T. (1989). Toward and interactional theory of delinquency. Criminology, 25, 863-892. 
Wellford, C. (1989). Towards an integrated theory of criminal behavior. In S. Messner, M. Krohn, \& A. Liska (Eds.), Theoretical integration in the study of deviance and crime: problems and prospects. Albany, NY: SUNY Press.

Publisher's Note Springer Nature remains neutral with regard to jurisdictional claims in published maps and institutional affiliations. 